\title{
ANALISIS CACING SUTERA (Tubifex tubifex) SEBAGAI BIOINDIKATOR PENCEMARAN AIR SUNGAI GORONG LOMBOK TENGAH
}

\author{
ANALYSIS OF BLOODWORM (Tubifex tubifex) AS BIOINDICATOR OF WATER POLLUTION AT \\ GORONG RIVER CENTRAL LOMBOK
}

\author{
Enida Fatmalia \\ Program Studi D3 Sanitasi,Sekolah Tinggi Teknik Lingkungan (STTL) Mataram. Jalan Bung Karno No. 60 \\ Pagesangan Timur, Mataram 83127 Indonesia \\ *Email: enidafatmalia@gmail.com
}

Diterima: 23 April 2018. Disetujui: 24 September 2018. Dipublikasikan: 25 September 2018

\begin{abstract}
Abstrak. Penelitian ini bertujuan untuk mengetahui keberadaan dan distribusi cacing Tubifex tubifexdi Sungai Gorong Desa Pengadang Lombok Tengah. Subyek penelitian ini adalah Tubifex tubifex. Jenis penelitian yang dilakukan adalah penelitian deskriptif eksploratif. Adapun fokus kajian pada penelitian ini adalah (1) keberadaan dan distrbusi cacing Tubifex tubifex di sungai Gorong Desa Pengadang yang dapat dijadikan sebagai bioindikatorpencemaran lingkungan, (2) status pencemaran sungai Gorong Desa Pengadang berdasarkan bioindikator cacing Tubifex tubifex. Teknik pengambilan sampel menggunakan beberapa tahapan, yaitu: (1) Persiapan plot, (2) Pengambilan sampel lumpur, (3) Langkah-langkah pengambilan sampel cacing sutera (Tubifex tubifex), dan (4) menyiapkan tabel pengamatan jenis cacing yang ditemukan. Hasil penelitian menunjukkan bahwa jumlah Tubifex tubifexyang ditemukan yaitu sebanyak 79 ekor pada stasiun I, 71 ekor pada stasiun II, dan 13 ekor pada stasiun III, dengan total 163 ekor. Berdasarkan paparan data di atas dapat disimpulkan bahwa cacing Tubifex tubifexdapat dijadikan sebagai bioindikator pencemaran air dan sungai Gorong Desa Pengadang dikategorikan ke dalam perairan yang tercemar.
\end{abstract}

Kata kunci: Keberadaan dan Distribusi, Tubifextubifex, Bioindikator, Pencemaran Air

Abstract. This study aims to determine the existence and distribution of tubifex tubifex in Gorong river central Lombok. The subject of this study was tubifex tubifex. The research types was explorative descriptive research. The study was focused in (1) the existence and distribution of Tubifex tubifex worms in the Gorong river which can be used as bio-indicators of environmental pollution, (2) pollution status of the Gorong river based on bioindicator tubifex tubifex. The sampling technique used several stages, namely: (1) plot preparation, (2) taking mud samples, (3) steps for sampling tubifex tubifex, and (4) preparing an observation data for the worms types found. The results showed that the number of tubifex tubifex found was 79 worms at station I, 71 worms at station II, and 13 warms at station III, with a total of 163 worms. In conclusion, the tubifex tubifex worms could be used as bio-indicators of water pollution and the Gorong river was categorized as highly polluted river.

Keywords: Existence and Distribution, Tubifextubifex, Water Pollution, Bioindicators

\section{PENDAHULUAN}

Pencemaran air sungai biasanya terjadi di kawasan industri akibat limbah pabrik. Namun tidak menutuk kemungkinan pencemaran air juga terjadi pada daerah yang memiliki industri tidak terlalu banyak seperti beberapa sungai di pulau Lombok [1-3]. Sebagai salah satu sumber perairan di Desa Pengadang Kabupaten Lombok Tengah, kebersihan Sungai Gorong layak untuk diperhitungkan guna menjaga kesehatan lingkungan di Desa Pengadang itu sendiri. Namun dengan adanya aktivitas masyarakat seperti perdagangan, pembangunan serta bertani dengan menggunakan pupuk kandang oleh masyarakat Desa Pengadang menjadi kekhawatiran mengenai kebersihan air sungai Gorong ini. Hal ini dapat dilihat dari banyaknya kotoran sapi disetiap Kepala Keluarga (KK), penumpukan dedaun-daunan, tidak adanya tempat sampah, sehingga masih memerlukan perbaikan terutama dalam pengelolaan sampah (lingkungan).

Dengan demikian karena belum adanya tempat sampah yang memadai sehingga ketika musim penghujan datang banyak diantara kotoran-kotoran sapi dan sampah organik yang ikut terbuang bersama air menuju ke sungai Gorong, sehingga menyebabkan penimbunan lumpur kotoran sapi dan jenis sampah yang lain (sampah organik) di sekitar sungai Gorong. 
Berdasarkan pemeparan di atas, besar kemungkinan terjadi pencemaran air di Sungai Gorong ini.

Dalam rangka analisis keadaan lingkungan, masalah indikator biologis perlu diketahui dan ditentukan. Indikator yang digunakan adalah organisme yang biasanya hidup di perairan dengan kadar oksigen rendah yaitu cacing Sutera(Tubifex tubifex), sehingga keberadaan Tubifex tubifex sering dijadikan indikator perairan yang tercemar [4-7]. Bentuk tubuh cacing ini menyerupai rambut dengan panjang badan antara 1-3 cm dengan tubuh berwarna sutera kecoklatan dengan ruas ruastubuhnya sepanjang 1-2 cm, terdiri dari 30-60 segmen atau ruas [8-9].

Selain itu, cacing yang termasuk ke dalam subkelas Oligochaeta ini mudah dikenali, hidup dan berkembang biak lebih cepat apabila ada limbah organik jika dibandingkan dengan bioindikator lain.Mengingat sungai Gorong di Desa Pengadang ini merupakan kawasan yang kaya akan limbah organik atau limbah domestik. Terlepas dari itu, informasi ilmiah yang mengungkap tentang keberadaan cacing Tubifex tubifexdi daerah ini sangatlah terbatas, sehingga pemahaman masyarakat tentang pentingnya pengetahuan cacing Tubifex tubifexsangat minim khususnya para pemerhati lingkungan.

\section{METODE PENELITIAN}

Penelitian ini dilakukan di sungai Gorong Desa Pengadang Kecamatan Praya Tengah, selama 14 hari yaitu mulai dari tanggal 20 Januari sampai 02 Februari 2016 dengan subyek penelitian yaitu semua cacing Tubifex tubifex yang terdapat padasungai Gorong Desa Pengadang.Adapun alur penelitian ini adalah sebagai berikut:

\section{Persiapan Alat Penelitian}

Alat-alat yang digunakan dalam pengambilan data primer yaitu Kameradigital, Ballpoint dan buku catatan, Tali rafia, Kalkulator, Termometer, $\mathrm{pH}$ meter, Pisau pemotong, Kantong plastik, Meteran, Alat keruk (centongan), Bak/ Ember dan Alat penyaring (sive net) dengan lebar mata saring $0,5 \mathrm{~mm}$.

2. TeknikPengumpulan Data

Dalam penelitian ini, teknik pengumpulan data yang digunakan melalui 2 tahapan yaitu (a) persiapan plotsetiap stasiun yang terdiri atas 3 plot pada sisi kiri, 3 plot pada sisi tengah, dan 3 plot sisi kanan, sehingga secara keseluruhan berjumlah 27 plot dalam 3 stasiun (b) Pengambilan sampel lumpur menggunakan saringan (sive net).

3. Lokasi Penelitian

Lokasi penelitian terbagi menjadi 3 stasiun yakni stasiun I di Dusun Sempelek dengan kondisi substrat dasar lumpur berpasir, stasiun II di Dusun Perentek dengan kondisi substrat dasar lumpur berpasir, dan Stasiun III merupakan daerah tanpa aktivitas masyarakat dengan substrat dasar lumpur berpasir dan berbatu.

4. Pengukuran faktor abiotik, fisik dan kimia

a. Mengukur kedalaman sungai dengan meteran dengan ketelitian $1 \mathrm{~cm}$

b. Mengukur suhu air sungai

c. Kandungan bahan organik (porsi)

d. $p H$ lumpur

5. Teknik Analisis Data

Teknik analisis Tubifex tubifex yang ditemukan menggunakan analisis regresi (Linier Sederhana).Analisis regresi bertujuan untuk membuat keputusan tentang naik dan turunnya variabel independent. Atau apakah naik dan turunnya populasi Tubifex tubifex dengan kandungan C-Organik, dengan rumus [10] berikut:

$\hat{\mathrm{Y}}=\mathrm{a}+\mathrm{bX}$

Keterangan: $\hat{Y}=$ subyek dalam variabel dependen yang diprediksikan; a = harga $\mathrm{Y}$ ketika harga $\mathrm{X}=$ 0 (harga konstan); $b=$ angka arah atau koefisien regresi, yang menunjukkan angka peningkatan ataupun penurunan variabel dependen berdasarkan pada perubahan variabel independen. Bila (+) arah garis naik, dan bila (-) maka garis turun; $\mathrm{X}=$ subyek pada variabel independen yang mempunyai nilai tertentu

$$
\mathrm{a}=\frac{\left(\Sigma \mathrm{Y}_{\mathrm{i}}\right)\left(\Sigma \mathrm{X}_{\mathrm{i}}\right)^{2}-\left(\Sigma \mathrm{X}_{\mathrm{i}}\right)\left(\Sigma \mathrm{X}_{\mathrm{i}} \mathrm{Y}_{\mathrm{i}}\right)}{\mathrm{n} \Sigma \mathrm{X}_{\mathrm{i}}^{2}-\left(\Sigma \mathrm{X}_{\mathrm{i}}\right)^{2}} \mathrm{~b}=\frac{\mathrm{n} \Sigma \mathrm{X}_{\mathrm{i}} \mathrm{Y}_{\mathrm{i}}-\left(\Sigma \mathrm{X}_{\mathrm{i}}\right)\left(\Sigma \mathrm{Y}_{\mathrm{i}}\right)}{\mathrm{n} \Sigma \mathrm{X}_{\mathrm{i}}^{2}-\left(\Sigma \mathrm{X}_{\mathrm{i}}\right)^{2}}
$$

\section{HASIL DAN PEMBAHASAN}

\section{Kelimpahan Cacing Tubifex tubifex}

Jumlah Tubifex tubifex yang ditemukan di Sungai Gorong adalah 163.Spesies ini mampu mentolelir keadaan perairan yang dikelompokkan ke dalam kelompok toleran.

Perbedaan jumlah Tubifex tubifex pada setiap stasiun disebabkan karena nilai dan kandungan parameter fisik dan kimia yang tidak merata.Jumlah tertinggi berada pada stasiun I. Hal ini disebabkan stasiun I memiliki kondisi fisika dan kimia perairan yang paling sesuai dengan habitatnya, selain itu disertai juga berdasarkan uji laboratorium dengan kondisi substrat (C-Organik) yang memiliki kandungan paling banyak yaitu 2,62 \% (tabel 2). 
Tabel 1. Kelimpahan Cacing Tubifex tubifex

\begin{tabular}{ccccccccccc}
\hline & \multicolumn{10}{c}{ Kelimpahan Cacing Tubifex tubifex } \\
Stasiun ke- & \multicolumn{1}{c}{ Plot Ke- } & \multirow{2}{*}{$\sum$} \\
\cline { 2 - 11 } & $\mathbf{1}$ & $\mathbf{2}$ & $\mathbf{3}$ & $\mathbf{4}$ & $\mathbf{5}$ & $\mathbf{6}$ & $\mathbf{7}$ & $\mathbf{8}$ & $\mathbf{9}$ & \\
\hline I & 11 & 12 & 4 & 16 & 5 & 3 & 10 & 8 & 10 & 79 \\
II & 17 & 11 & 13 & 4 & 7 & 7 & 2 & 5 & 5 & 71 \\
III & 2 & 1 & 5 & - & 1 & - & - & 4 & 1 & 13 \\
\hline \multicolumn{10}{c}{ Total } \\
\hline
\end{tabular}

Tabel 2. Nilai faktor fisik kimia yang diperoleh di Sungai Gorong Desa Pengadang

\begin{tabular}{|c|c|c|c|}
\hline \multirow{2}{*}{ Parameter uji } & \multicolumn{3}{|c|}{ Stasiun } \\
\hline & $\mathbf{I}$ & II & III \\
\hline Suhu & $20,13^{0} \mathrm{C}$ & $20^{0} \mathrm{C}$ & $19,66 \mathrm{v}$ \\
\hline pH lumpur & 7,33 & 8 & 7,33 \\
\hline Jenis substrat & Lumpur berpasir & Lumpur berpasir & $\begin{array}{l}\text { Lumpur berpasir } \\
\boldsymbol{B}_{r} \text { horhatis }\end{array}$ \\
\hline Kedalaman sungai & $63,71 \mathrm{~cm}$ & $37,7 \mathrm{~cm}$ & $48,06 \mathrm{~cm}$ \\
\hline $\begin{array}{l}\text { Kandungan C- } \\
\text { Oraanik }\end{array}$ & $2,62 \%$ & $1,61 \%$ & $1,05 \%$ \\
\hline
\end{tabular}

Stasiun III mempunyai perbedaan yang sangat signifikan jika dibandingkan dengan stasiun I dan II, yaitu mulai dari jenis substrat dasar, $\mathrm{pH}$, suhu dan kedalaman yang berbeda sehingga menyebabkan sedikitnya jumlah spesies yang ditemukan.Hal ini didukung oleh Khairuman, dkk.(2010), menyatakan bahwacacing Tubifex tubifex menyukai dasar perairan yang banyak mengandung bahan-bahan organik terlarut merupakan habitat kesukaannya.

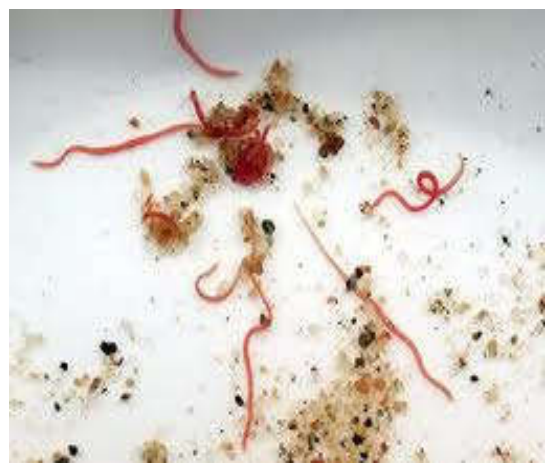

Gambar 1.Hasil pengambilan sampel spesies Tubifex tubifex

\section{Kondisi Faktor Lingkungan dengan Parameter Fisika dan Kimia}

Berdasarkan penelitian yang dilakukan di Sungai Gorong Desa Pengadang diperoleh nilai rata-rata faktor fisik-kimia pada setiap stasiun, seperti tertera pada tabel 2. Hal ini disebabkan karena ada dan tidak adanya aktivitas masyarakat dan mempunyai suhu yang relatif sama. Pernak (1978) dalam Triyanto (2006) menyatakan bahwa suhu air bukanlah merupakan faktor pembatas bagi oligochaeta akuatik.Semakin tinggi suhu air maka semakin menurun kualitasnya karena oksigen yang terlarut rendah dan mengakibatkan sedikitnya mikroorganisme yang mampu hidup.Suhu juga mempengaruhi laju fotosintesis, fisiologis hewan danperkembangan reproduksi, karena reaksi enzimatik yang berperan dalam fotosintesis dikendalikan oleh suhu [11].

Perairan yang memiliki bahan pencemar tinggi akan memiliki $\mathrm{pH}$ yang rendah. Rendahnya $\mathrm{pH}$ air menunjukkan banyaknya limbah yang dibuang ke badan sungai dan tidak dapat terpulihkan secara alamiah (self purification) oleh air sungai. Limbah tersebut dapat berupa Partikel Terlarut Tersuspensi (TSS) maupun yang bersifat koloid [12].

Menurut Vincentius [13] menyatakan bahwa ketinggian air pada lingkungan pemeliharaan cacing Tubifex tubifex berpengaruh terhadap ketahanan hidup dan perkembangannya. Jika air terlalu tinggi, maka koloni atau populasi cacing Tubifex tubifex akan tidak berkembang bahkan akan mengalami kematian karena cacing Tubifex tubifex ini membutuhkan oksigen dari luar untuk bernapas. Sedangkan apabila air terlau rendah atau sedikit, maka lingkungannya akan cepat panas sehingga cacing Tubifex tubifex ini tidak akan dapat bertahan hidup lebih lama. Ketinggian air yang optimal pada populasi cacing Tubifex tubifex adalah setinggi $6 \mathrm{~cm}[13]$. 
Secara keseluruhan nilai kandungan C-Organik yang didapatkan dari ketiga stasiun penelitian di Sungai Gorong Pengadang ini tergolong rendah dan sangat rendah. Menurut metode Walkey-Black kriteria C-Organik dapat dilihat pada tabel 3.

Tabel 3. Borad rating of organik carbon measurements* [14]

\begin{tabular}{ll}
\hline $\begin{array}{c}\text { Organic Content Walkey- } \\
\text { Black method (\% of soil by } \\
\text { weight) }\end{array}$ & \multicolumn{1}{c}{ Rating } \\
\hline$>20$ & Very high \\
$10-20$ & High \\
$4-10$ & Medium \\
$2-4$ & Low \\
$<2$ & Very low \\
\hline
\end{tabular}

Tubifex tubifex adalah golongan Oligochaeta akuatik yang hidup di dalam lumpur pada dasar sungai atau danau. Jenis subtrat pada stasiun I dan II adalah substrat lumpur berpasir sehingga kurang cocok untuk kehidupan Tubifex tubifex.

\section{Hasil Analisis Regresi (Linier Sederhana)}

Dari persamaan regresi dapat diartikan bahwaapabila nilai kandungan C-organik bertambah 1\%, maka nilai populasi Tubifex tubifex tiap stasiun akan bertambah 80 , atau setiap nilai kandungan COrganik bertambah 10 maka nilai rata-rata kenaikan populasi Tubifex tubifex tiap stasiun 800 .

Dari gambar 2 di bawah ini dapat dilihat bahwa semakin banyak kandungan C-Organik lumpur yang terdapat dalam setiap stasiun pengamatan maka semakin banyak jumlah Tubifex tubifex yang ditemukan.

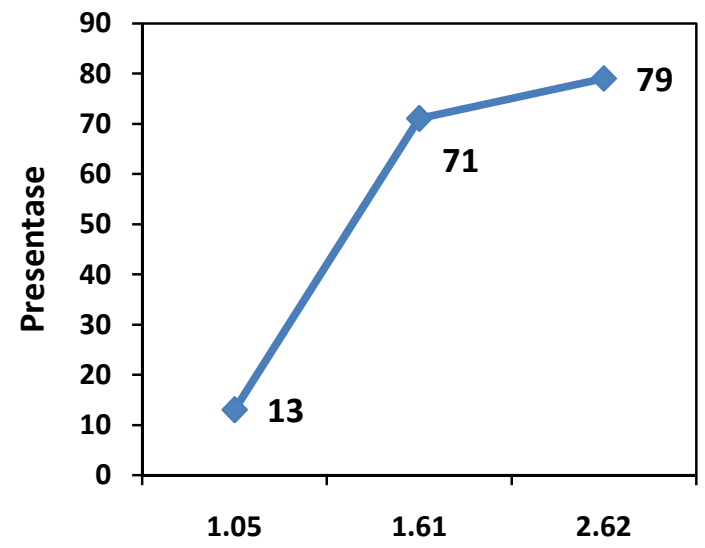

Gambar 2.Garis regresi nilai C-Organik dan nilai populasi Tubifex tubifex

\section{KESIMPULAN}

Dari hasil penelitian dan pembahasan dapat disimpulkan sebagai berikut:
1. Cacing Tubifex tubifex dapat sebagai biondikator pencemaran air, ini dapat dilihat dari semakin banyak kandungan bahan organik pada sungai semakin banyak pula cacing Tubifex tubifex yang ditemukan di Sungai Gorong Desa Pengadang dijadikan sebagai bioindikator pencemaran lingkungan (perairan).

2. Cacing Tubifex tubifexditemukan di Sungai Gorong Desa Pengadang Lombok Tengah, dinyatakan kedalam kelompok perairan yang tercemar. Di sisi lain substrat yang kurang mendukung perkembangbiakan Tubifex tubifex sehingga kelimpahan cacing ini tidak terlalu banyak pada lokasi penelitian.

\section{SARAN}

1. Untuk memperoleh data yang lebih lengkap tentang keberadaan dan kelimpahan cacing Tubifex tubifex maka perlu penelitian yang dilaksanakan dalam jangka waktu relatif lama dan area sampel yang lebih dengan tingkat keberadaan dan kelimpahan cacing Tubifex tubifex di Sungai Gorong Desa Pengadang.

2. Selain itu perlu dilakukan penelitian lebih lanjut tentang faktor fisika dan kimia yang lain terhadap keanekaragaman populasi, terutama dari jenis-jenis yang melimpah seperti Tubifex tubifex, untuk usaha penggunaannyasebagai bioindikator kualitas air.

\section{DAFTAR PUSTAKA}

[1] Rudiyanti, S. (2011). Kualitas perairan sungai Banger Pekalongan berdasarkan indikator biologis. SAINTEK PERIKANAN: Indonesian Journal of Fisheries Science and Technology, 4(2), 46-52.

[2] Al Idrus, S. W. (2015). Analisis Pencemaran Air Menggunakan Metode Sederhana Pada Sungai Jangkuk, Kekalik Dan Sekarbela Kota Mataram. Jurnal Pijar Mipa, 10(2).

[3] Rahmawati, A., Kusmiyati, K., \& Ilhamdi, M. L. (2017). Keanekaragaman Makrozoobenthos Di Daerah Aliran Sungai (DAS) Unus Kota Mataram. Jurnal Pijar Mipa, 12(2), 86-90.

[4] Kaonga, C. C., Kumwenda, J., \& Mapoma, H. T. (2010). Accumulation of lead, cadmium, manganese, copper and zinc by sludge worms; Tubifex tubifex in sewage sludge. International Journal of Environmental Science \& Technology, 7(1), 119-126.

[5] Shuhaimi-Othman, M., Nadzifah, Y., Umirah, N. S., \& Ahmad, A. K. (2012). Toxicity of metals to an aquatic worm, Nais elinguis (Oligochaeta, Naididae). Research Journal of Environmental Toxicology, 6(4), 122-132. 
[6] Panich-Pat, T., Yenwaree, W., \& Ongmali, R. (2009). Monitoring Of Water Quality Using Phytoplankton, Protozoa, And Benthos As Bioindicator In Chadeebucha Canal, Nakhon Pathom Province. Applied Environmental Research, 31(2), 1-14.

[7] Imoobe, T. O. T., \& Ohiozebau, E. (2010). Pollution status of a tropical forest river using aquatic insects as indicators. African Journal of Ecology, 48(1), 232-238.

[8] Sedana, I. G. M. A., Darmadi, N. M., \& Arya, I. W. (2018). Analisis Tingkat Pencemaran Air Sungai Yeh Sungi di Kabupaten Tabanan Dengan Menggunakan Indikator Biologis NVC Ikan dan Keragaman Jenis Makrozoobenthos. GEMA AGRO, 23(1), 79-91.

[9] Anggaraini, N. (2017). Penggunaan Media Kultur Hasil Fermentasi Berbeda Terhadap Pertumbuhan Populasi Cacing Sutera (limnodrilus sp). Jurnal Ilmu-Ilmu Perikanan dan Budidaya Perairan, 12(1).

[10] Sugiyono.2010. Statistika untuk Penelitian. Bandung: Alfabeta.

[11] Mindasari, L. Dampak Kegiatan Pertambangan Batubara PT. Tambang Batubara Bukit Asam (PT. BA)(Persero).

[12] Prat, N., Rieradevall, M., Barata, C., \& Munné, A. (2013). The combined use of metrics of biological quality and biomarkers to detect the effects of reclaimed water on macroinvertebrate assemblages in the lower part of a polluted Mediterranean river (Llobregat River, NE Spain). Ecological indicators, 24, 167-176.

[13] Subekti, S., Prawesti, M., \& Arief, M. (2011). Pengaruh kombinasi pakan buatan dan pakan alami cacing sutera (Tubifex tubifex) dengan persentase yang berbeda terhadap retensi protein, lemak dan energi pada ikan sidat (Anguilla bicolor). Jurnal Kelautan: Indonesian Journal of Marine Science and Technology, 4(1), 90-95.

[14] Landon, J. R. (1984). Booker tropical Soil Manual. Booker Agricultural International Limited. 